\title{
Feeding habits of omnivorous Asplanchna: comparison of diet composition among Asplanchna herricki, $A$. priodonta and $A$. girodi in pond ecosystems
}

\author{
Kwang-Hyeon CHANG*, Hideyuki DOI ${ }^{1)}$, Yuichiro NISHIBE ${ }^{2)}$ and Shin-ichi NAKANO ${ }^{3)}$ \\ Center for Marine Environmental Studies (CMES), Ehime University, Bunkyo-cho 2-5, Matsuyama 790-8577, Japan \\ Present address: Department of Environmental Science and Engineering, Kyung Hee University, Seochen-dong 1, Giheung-gu, \\ Yongin-Si, Gyeonggi-Do 446-701, Republic of Korea \\ ${ }^{1)}$ Institute for Chemistry and Biology of the Marine Environment, Carl-von-Ossietzky University Oldenburg, Scheusenstrasse 1 D- \\ 26382, Wilhelmshaven, Germany \\ ${ }^{2)}$ Ocean Research Institute, University of Tokyo, 1-15-1 Minamidai, Nakano-ku, Tokyo 164-8639, Japan \\ ${ }^{3)}$ Center for Ecology, Kyoto University, Hirano 2-509-3, Otsu 520-2113, Japan \\ *e-mail corresponding author: changkwang38@hotmail.com
}

\begin{abstract}
Spatial distribution and the diet composition of Asplanchna species were studied in 18 water bodies in Matsuyama, Japan. The abundance of Asplanchna and other rotifers, crustaceans, phytoplankton and microbial plankton, together with basic environmental parameters, were determined between October and December 2006, and the distribution and diet composition of Asplanchna species were estimated. Three species of Asplanchna, A. herricki, A. priodonta and A. girodi were found in the present study, but A. herricki was rather less abundant than the other two species. Their diet composition was different among the species, showing that A. herricki consumed only particulate matter while the diet of A. priodonta included mainly phytoplankton, dominated by dinoflagellates. In contrast, A. girodi was rather carnivorous, and included other rotifers in its diet. Their different food habits are not explained by their morphotypes and trophi structures, suggesting this difference might be related to their feeding abilities. For A. girodi, prey selectivity (Chesson's $\alpha$ ) for rotifer prey was negative, except for Keratella cochlearis. The amount of rotifers consumed was also low at a mean prey number of less than 3 per A. girodi gut. The result suggests that the predation impact of Asplanchna as a top-down controller of rotifer populations is species-specific and can be apparent only when Asplanchna population reaches high density in these ponds. From the present results, three Asplanchna species were found to belong to basically different feeding groups, A. herricki is detritivore while A. priodonta and A. girodi are omnivores; but A. girodi is more predacious.
\end{abstract}

Key words: rotifer, gut contents, feeding selectivity

\section{INTRODUCTION}

Omnivory is an important interaction that has been the subject of numerous theoretical studies in recent years, with particular focus on how trait differences in omnivorous organisms will alter food webs (Kneitel 2007). In empirical studies, particularly in plankton ecology, investigating the feeding behavior of organisms is important (e.g., Colin et al. 2005), since there are still many species of which feeding habits and their overall trophic positions in the aquatic food web are not yet clearly understood. In particular, for omnivorous zooplankton, it is difficult to define their trophic position because they often show different prey preferences depending on a variety of factors such as their body size, trait differences of the prey organisms, and prey availability in their environments (Adrian \& Frost 1993; Gifford et al. 2007).

The genus Asplanchna is a common omnivorous rotifer distributed from temperate to tropical waters (Fernando et al. 1990). They are mainly known as predators on rotifers, and thus their predation has been suggested as one important factor controlling the dynamics of their prey populations. Their presence is also known to provide chemical cues inducing the morphological defenses of some rotifer prey species (Gil- bert 1980a; Stemberger 1990; Dumont \& Sarma 1995). However, some results of studies of their feeding habits have suggested that they have different diet compositions, and consequently have different prey preferences, among species. One well known predatory species is Asplanchna brightwelli (Gosse). From laboratory experiments and field observations of its diets, $A$. brightwelli is known to consume a wide range of prey from protists (Paramecium and Euglena) to various rotifer species, including those of the genera Anuraeopsis, Brachionus and Keratella (Maly 1975; Urabe 1992; Sarma et al. 1998). In contrast, Asplanchna priodonta (Gosse), although it is known as typically omnivorous, often consumes colonial algae and even cyanobacteria rather than zooplankton prey (Kappes et al. 2000; Pociecha \& Wilk-Woźniak 2008).

However, though multiple species of Asplanchna are frequently observed in many water bodies, the precise species composition of Asplanchna populations and their different feeding habits are often ignored since their body shapes are very similar and identification based on the morphology of their trophi is difficult and time-consuming. In the present study, for better understanding of their trophic role and predation impacts on prey populations in the aquatic food web, we estimated Asplanchnas' specific feeding habits, and the possible 
factors affecting their diet composition in the present study.

Various factors influencing their species-specific feeding behavior, including 1) different structure of trophi, 2) external environments such as prey density and chemical composition of the water and 3) swimming and capture abilities, have been suggested as probable determining factors of their diet compositions (Salt et al. 1978; Salt 1987; Urabe 1992; Kappes et al. 2000). However, the feeding behaviors of Asplanchna species are still insufficiently understood. Therefore, to determine the species-specific feeding habits of Asplanchna species and its relation with their trophi structure and external environmental factors, we collected zooplankton from various ponds, closely located but having different environmental characteristics, and compared the diet compositions of Asplanchna species. We identified the Asplanchna species based on the morphology of the trophi, and analyzed their diet and its relationships with the environmental parameters investigated.

\section{MATERIALS AND METHODS}

The plankton samples were collected from 18 ponds in Matsuyama, Shikoku, Japan. The ponds are located between $33^{\circ} 48^{\prime}-50^{\prime} \mathrm{N}$ and $132^{\circ} 48^{\prime}-55^{\prime} \mathrm{E}$. All samples were collected once for each pond during autumn (between October and November 2006). Samplings were carried out at the deepest point of each water body.

Water temperature, dissolved oxygen concentration (DO), $\mathrm{pH}$, conductivity, Secchi disk transparency, Chl- $a$ concentration and nutrient concentrations were measured as environmental parameters. Water temperature and dissolved oxygen concentration were measured with a DO meter (55-12FT, YSI) at $0.5 \mathrm{~m}$ depth. The water from the surface to $0.5 \mathrm{~m}$ was collected using a column sampler (diameter, $5 \mathrm{~cm}$; total length, $62 \mathrm{~cm}$ ) with a flap at the bottom operated hydraulically. This sampler was designed for collecting water from the surface to a certain depth. From the collected water, $\mathrm{pH}$ and conductivity were measured with Twin $\mathrm{pH}$ (Horiba, Ltd., Japan) and Twin Cond (Horiba, Ltd., Japan) meters, respectively. Nutrients (dissolved inorganic nitrogen: $\mathrm{N}^{-\mathrm{NO}_{2}}$, $\mathrm{N}-\mathrm{NO}_{3}$ and $\mathrm{N}-\mathrm{NH}_{4}$; soluble reactive phosphorus: $\mathrm{P}^{-} \mathrm{PO}_{4}$; dissolved silica: $\mathrm{SiO}_{2}$ ) were measured using an Autoanalyzer (BRAN+LUEBEE, Traacs 800). The Chl- $a$ concentration was determined using a 10-AU Fluorometer (TURNER DESIGNS).

A water sample from the surface to $1.5 \mathrm{~m}$ depth was also taken using a column sampler for collecting protozoa, bacteria, heterotrophic nanoflagellates (HNF) and rotifers. For bacteria and HNF, $100 \mathrm{~mL}$ of the water was preserved with glutaraldehyde. Bacterial and HNF densities were estimated using an epifluorescence microscope with ultraviolet excitation (excitation wave length 330 to $385 \mathrm{~nm}$ ) using the DAPI (Porter \& Feig 1980) and primulin (Caron 1983) staining methods, respectively. For protozoa, $500 \mathrm{~mL}$ of the collected water was fixed with Lugol's solution, and cell densities were estimated using a Burker-Turk counting chamber. The rest of the water sample (from 4.5 to 8.81 water) was filtered through a plankton net $(60 \mu \mathrm{m}$ mesh), and preserved with formalin (final concentration approximately $5 \%$ ) for the counting and identification of rotifers. Large but low-density zooplankton, including Asplanchna, cladocerans and copepods were collected with a vertical tow net ( $200 \mu \mathrm{m}$ mesh-net) from near the bottom to the surface at each pond.

For the identification and diet analyses, commercial bleach was added to the isolated Asplanchna individuals to extract their trophi and gut contents, and dissolve the organic matter (Schoeneck et al. 1990). Extracted rotifer trophi and other plankton prey were identified and counted. We identified the trophi of Asplanchna (Fig. 1) and prey rotifer species according to Jersabek et al. (2003). For A. girodi (de Guerne), whose diets included enough rotifers for the calculation, the selectivity of rotifer species was calculated using Chesson's selectivity index $(\alpha)$ :

$$
\text { Selectivity index }(\alpha)=\left(r_{i} / p_{i}\right) /\left(r_{i} / p_{i}+r_{j} / p_{j}\right)
$$

where $r_{i}$ is the proportion of prey class $i$ in the stomach and $p_{i}$ is the proportion in the environment, while $r_{j}$ and $p_{j}$ are the proportions of other prey classes in the stomach and environment, respectively (Chesson 1978). The selectivity index ranged from 0 (negative selection) to 1 (positive selection), and no-selection was 0.5. For the comparison of Asplanchna diet compositions, a diet overlap index $\left(\alpha_{X}, Y\right)$ was calculated according to Zaret \& Rand (1971):

$$
\text { Overlap index }\left(\alpha_{X, Y}\right)=2 \times \sum X_{i} \times Y_{i} /\left(\sum X_{i}^{2}+\sum Y_{i}^{2}\right)(2
$$

where $X_{i}$ and $Y_{i}$ are the proportions of food item $i$ in the guts of $A$. girodi and $A$. priodonta, respectively. The index varies from 0 when the samples are completely distinct to 1 when the samples are identical with respect to proportional food category composition.

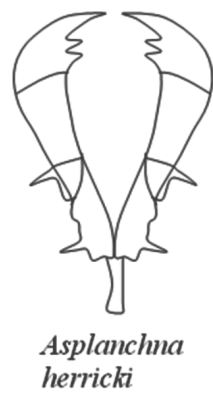

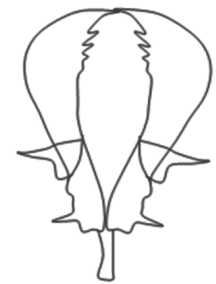

Asplanchna priodonta

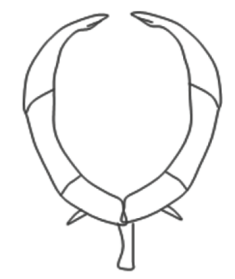

Asplanchna girodi
Fig. 1. Morphologies of the trophi of the three Asplanchna species.

Zooplankton biomass was obtained from available literature (Dumont et al. 1975; Culver et al. 1985). The ratio of calculated zooplankton biomass $\left(B_{z p}, \mu \mathrm{g} \mathrm{\textrm {L } ^ { - 1 }}\right.$ dry weight) and phytoplankton biomass $\left(B_{\text {phyt }}, \mu \mathrm{g} \mathrm{\textrm {L } ^ { - 1 }}\right.$ Chl-a 
Tab. 1. Summary of environmental parameters measured in the ponds. ${ }^{1)}$ Dissolved inorganic nitrogen (sum of $\mathrm{N}-\mathrm{NO}_{2}$, $\mathrm{N}-\mathrm{NO}_{3}$ and $\mathrm{N}-\mathrm{NH}_{4}$ concentrations); ${ }^{2)}$ Soluble reactive phosphorus $\left(\mathrm{P}_{-} \mathrm{PO}_{4}\right)$.

\begin{tabular}{|c|c|c|c|c|c|c|c|c|c|c|c|c|c|c|c|}
\hline 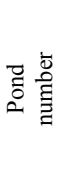 & 气ี & 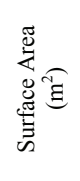 & 30 & $\stackrel{\mathbb{Z}}{2}$ & 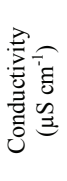 & 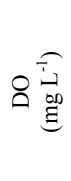 & 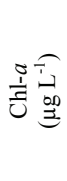 & 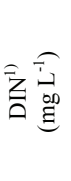 & 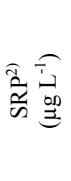 & 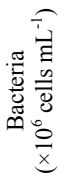 & 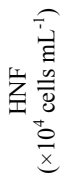 & 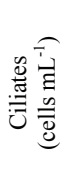 & 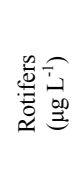 & 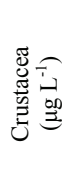 & 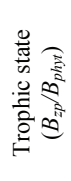 \\
\hline 1 & 4.7 & 26,948 & 18.4 & 6.5 & 187 & 7.41 & 18.1 & 14.0 & 0.37 & 2.8 & 3.6 & 10.0 & 45.5 & 136.5 & 10.0 \\
\hline 2 & 5.0 & 2201 & 17.6 & 7.1 & 168 & 10.69 & 102.7 & 70.5 & 0.08 & 3.4 & 4.2 & 20.2 & 228.8 & 97.3 & 3.2 \\
\hline 3 & 3.3 & 8792 & 17.3 & 9.6 & 182 & 13.1 & 111.8 & 0.7 & 0.73 & 2.5 & 2.3 & 15.4 & 196.3 & 254.1 & 4.0 \\
\hline 4 & 6.5 & 23,465 & 19.2 & 8 & 105 & 9.41 & 14.9 & 13.8 & 0.08 & 1.7 & 5.3 & 1.2 & 158.2 & 118.6 & 18.6 \\
\hline 5 & 2.5 & 5206 & 16.8 & 7.6 & 100 & 9.48 & 44.8 & 0.8 & 0.13 & 4.8 & 2.0 & 19.4 & 368.8 & 286.0 & 14.6 \\
\hline 6 & 5.0 & 13,631 & 17.8 & 7.1 & 105 & 10.2 & 18.5 & 18.3 & 1.72 & 6.3 & 0.8 & 2.4 & 347.2 & 910.7 & 67.9 \\
\hline 7 & 2.8 & 7901 & 17.4 & 7.3 & 140 & 8.03 & 13.2 & 15.6 & 0.11 & 9.0 & 0.4 & 4.3 & 1231.3 & 214.3 & 109.7 \\
\hline 8 & 2.0 & 985 & 18.5 & 7.6 & 85 & 9.16 & 2.7 & 22.8 & 0.11 & 6.3 & 0.1 & 0.8 & 39.3 & 66.8 & 39.3 \\
\hline 9 & 1.5 & 2592 & 19.1 & 9 & 182 & 13 & 37.4 & 1.0 & 0.24 & 11.5 & 7.5 & 69.7 & 255.6 & 5.1 & 7.0 \\
\hline 10 & 3.0 & 3633 & 19.5 & 9.9 & 220 & 13.01 & 60.5 & 11.7 & 0.29 & 6.2 & 5.9 & 119.2 & 167.9 & 118.3 & 4.7 \\
\hline 11 & 4.0 & 14,830 & 18.1 & 7.9 & 135 & 6.35 & 8.8 & 62.4 & 0.29 & 10.7 & 1.1 & 0.4 & 247.5 & 237.5 & 55.1 \\
\hline 12 & 2.6 & 3656 & 18.4 & 8.6 & 139 & 10 & 14.8 & 1.1 & 0.10 & 6.5 & 0.8 & 65.1 & 216.7 & 75.0 & 19.7 \\
\hline 13 & 7.1 & 4801 & 17.8 & 7.6 & 114 & 7.43 & 4.4 & 19.5 & 0.09 & 6.5 & 1.1 & 1.7 & 158.1 & 72.7 & 52.5 \\
\hline 14 & 4.1 & 6620 & 17.8 & 7.3 & 135 & 8.18 & 51.6 & 20.2 & 0.49 & 4.1 & 3.9 & 23.6 & 563.3 & 256.6 & 15.9 \\
\hline 15 & 3.2 & 18,400 & 18.4 & 8.2 & 149 & 7.93 & 42.2 & 35.6 & 0.16 & 4.2 & 8.0 & 42.4 & 248.0 & 171.7 & 10.0 \\
\hline 16 & 3.0 & 2802 & 18.5 & 9.6 & 180 & 10.58 & 55.7 & 1.2 & 0.12 & 4.0 & 4.9 & 67.5 & 688.0 & 101.4 & 14.2 \\
\hline 17 & 2.8 & 2392 & 18.2 & 8.3 & 210 & 9.3 & 21.9 & 19.3 & 0.13 & 3.7 & 2.5 & 191.3 & 1293.7 & 373.6 & 76.0 \\
\hline 18 & 3.0 & 1451 & 17.3 & 8.3 & 200 & 12.53 & 42.2 & 49.2 & 0.12 & 4.5 & 0.5 & 131.9 & 109.3 & 60.0 & 4.0 \\
\hline
\end{tabular}

concentration) was used to characterize the trophic state of each pond (Haberman \& Laugaste 2003). The relationships between the abundance of Asplanchna and environmental variables were tested with stepwise multiple regression. Statistical analyses, including stepwise multiple regression, ANOVA and $t$-test, were conducted using StatView (SAS Institute, Inc. USA). Cluster analyses of the rotifer species compositions at the study ponds were done with Primer 5 (Primer-E Ltd). For $A$. priodonta, which was collected from enough number of ponds to perform the analysis, the relationships between the quantities of diet components and environmental variables were analyzed using stepwise multiple regression method. A Canonical Correspondence Analysis (CCA) was carried out in order to estimate the relationships between the diet composition of $A$. priodonta and the environmental variables using CANOCO version 4.5 (ter Braak \& Smilauer 1998).

\section{RESULTS}

The sampled ponds had a variety of physical and chemical environments except their water temperatures which were within a narrow range, of 17.3 to $19.2{ }^{\circ} \mathrm{C}$ (Tab. 1). Most of the ponds were small artificial ponds, with water depths less than $10 \mathrm{~m}$. Biological parameters including abundances of prey, competitors and predators of Asplanchna, were also very variable among the ponds.

Asplanchna were collected from 13 out of the 18 ponds, and no Asplanchna were collected from ponds 3, 9, 12, 15 and 16. Abundance of Asplanchna was variable, reaching 620 ind $\mathrm{L}^{-1}$ at pond 7 , but usually lower than 100 ind $\mathrm{L}^{-1}$ (Fig. 2). Three species, A. herricki, $A$. priodonta and $A$. girodi, were collected throughout the sampling period, but $A$. herricki (de Guerne 1880) was collected from only 2 ponds. A. priodonta was more frequently observed than the other species. At two habitats, ponds 5 and 11, A. priodonta and A. girodi coexisted.
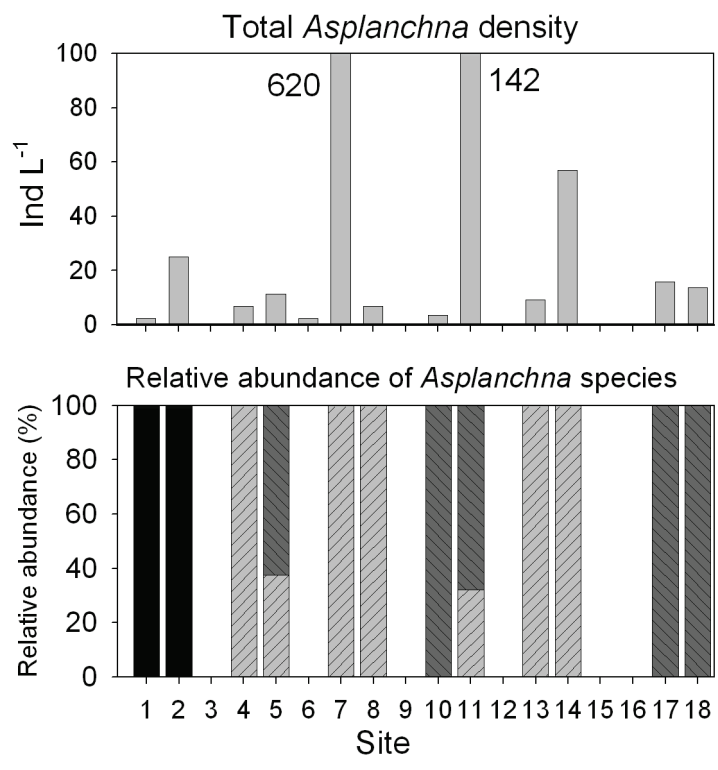

A. herricki $A$. priodonta

A. girodi

Fig. 2. Densities of Asplanchna species (upper) and relative abundances (lower) of each Asplanchna in the ponds.

Regardless of species, the total density of Asplanchna showed significant correlation only with the trophic state of the ponds $\left(B_{z p} / B_{p h y t}\right)$, and no significant relationship was observed with any other environmental parameters (Tab. 2). Moreover, the species distribution did not show any apparent pattern in relation to the 
Tab. 2. Summary of stepwise multiple regression between Asplanchna abundance and environmental parameters. *: statistically significant.

\begin{tabular}{clcc}
\hline Dependent variables & Independent variables & $F$ & $r^{2}$ \\
\hline Asplanchna density & $\begin{array}{l}\text { Trophic state } \\
\left(B_{z p} / B_{\text {phyt }}\right)\end{array}$ & 14.689 & 0.692 \\
& Heterotrophic & $0.0015)^{*}$ \\
& nanoflagellates (HNF) & 0.061 & 0.064 \\
& Bacteria & 1.862 & 0.332 \\
& Depth & 0.672 & -0.207 \\
& pH & 0.0001 & 0.003 \\
& Conductivity & 0.226 & 0.122 \\
& $\begin{array}{l}\text { Crustacean abundance } \\
\text { (dry weight) }\end{array}$ & 3.264 & -0.423 \\
& $\begin{array}{l}\text { Rotifer abundance } \\
\text { (dry weight) }\end{array}$ & 0.253 & 0.129 \\
& & & \\
\hline
\end{tabular}

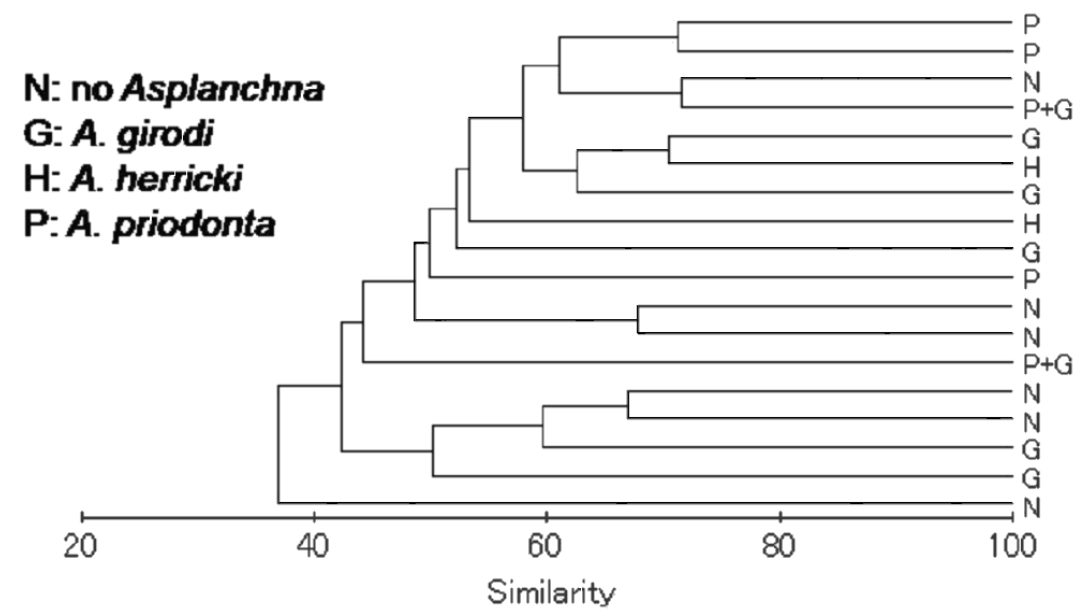

Fig. 3. Result of cluster analysis on rotifer species composition among the 18 ponds. The pond sites are classified according to the Asplanchna species present.

environmental parameters. According to the cluster analysis of the rotifers, the presence of three Asplanchna species showed no close relationship with other rotifer species' composition (Fig. 3).

The three Asplanchna species included various prey in their diets, but they did show different diet compositions among the species (Fig. 4). A. herricki consumed only particulate matter and no identifiable plankton prey was observed in this species. In contrast, both $A$. priodonta and $A$. girodi consumed various prey ranging from phytoplankton to even the cladoceran, Bosminopsis deitersi (Richard). However, the composition of their diet was different, with $A$. girodi feeding more carnivorously. We could confirm the different compositions of their diets from the ponds where these two species coexisted although they showed low overlap values, 0.348 (pond 5) and 0.267 (pond 11). A. priodonta mainly consumed dinoflagellates, particularly large Ceratium and Peridinium, and often consumed euglenoids and ciliates prey. However, their diet composition and the amount of food consumed were quite variable among the ponds. On the other hand, A. girodi also consumed phytoplankton and protozoa, but they consumed a larger amount of rotifers than $A$. priodonta. In most ponds, Keratella cochlearis (Gosse) was the dominant prey item in the diets of $A$. girodi. Among rotifer species which were consumed by $A$. girodi, $K$. cochlearis showed the only positive selection index, while other species showed negative selection, even though they were found in $A$. girodi guts (Fig. 5).

The quantities of phytoplankton and zooplankton in the diets of $A$. priodonta showed no significant relationships with the variables tested (body size of $A$. priodonta, bacterial and HNF abundances, Chl- $a$ concentration and rotifer abundance) in the stepwise multiple regression analyses. However, a CCA analysis did show that the diet composition of $A$. priodonta was related to prey abundances. The eigenvalues of CCA axis 1 (0.81) and axis $2(0.59)$, constrained to the variables, account for $56.7 \%$ of the cumulative variance in the species data. 


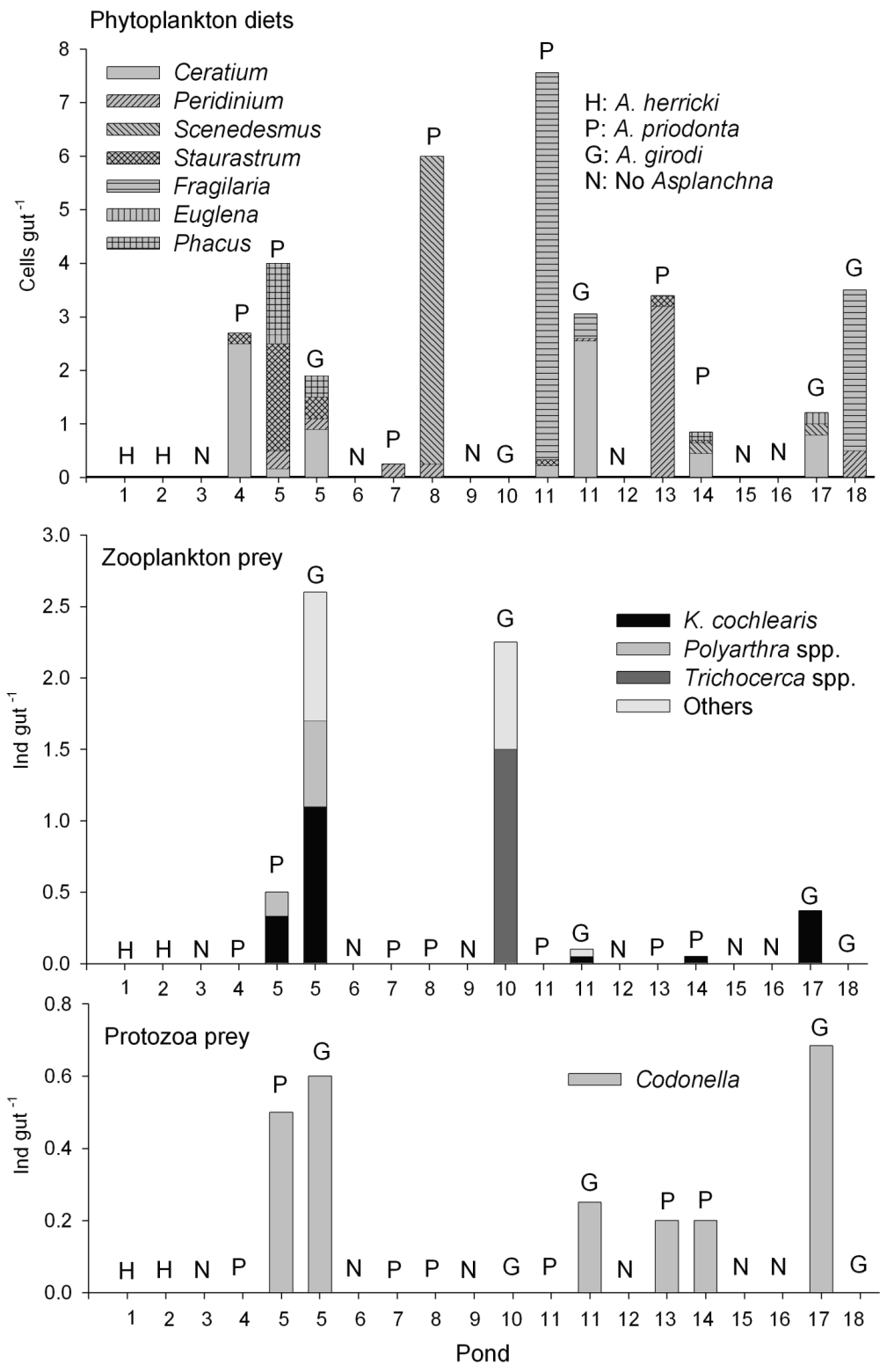

Fig. 4. Diet composition in the guts of Asplanchna species (top: phytoplankton, middle: zooplankton and bottom: protozoa prey groups) from the ponds.

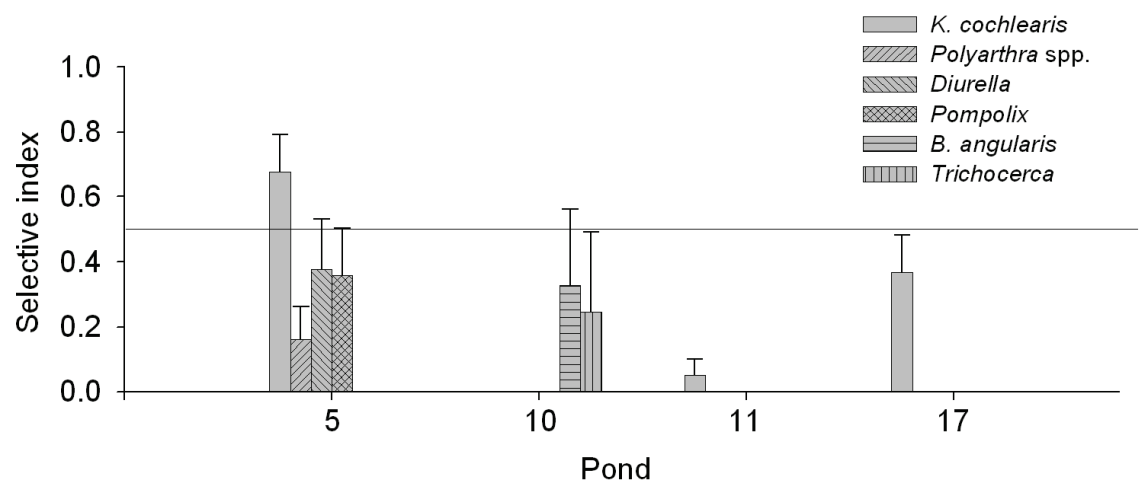

Fig. 5. Selective index $(\alpha)$ of $A$. girodi feeding on rotifer species in ponds 5, 10, 11 and 17. 


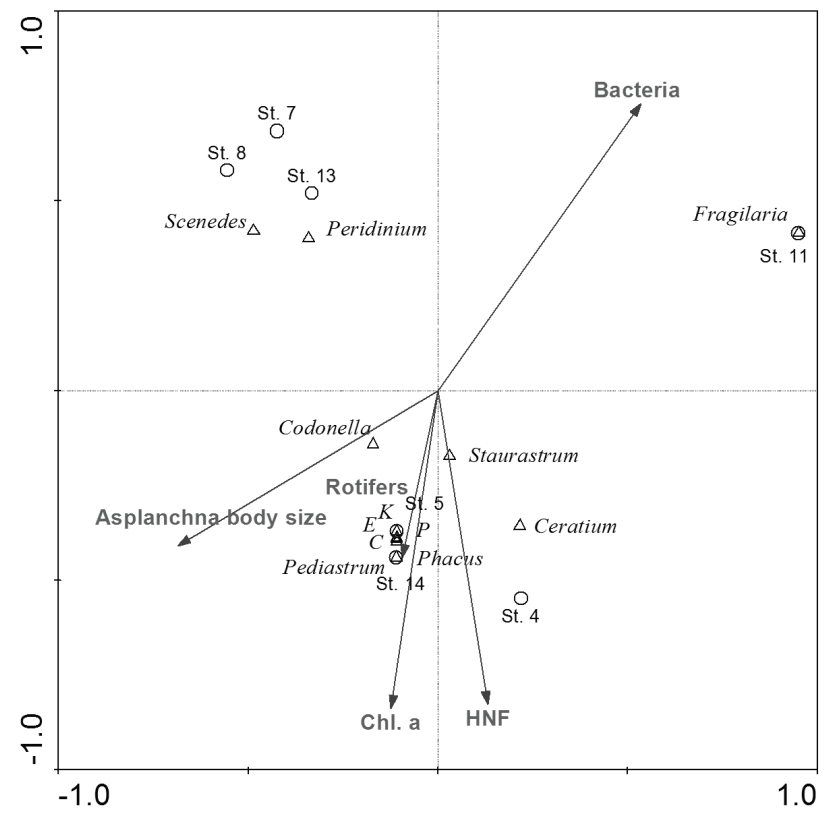

Fig. 6. Ordination diagram by CCA of the diet composition and of the pond sites. Circles represent the pond sites, triangles represent the species included in the Asplanchna guts and vectors represent the environmental variables. The vectors of the environmental variables are the abundances of rotifers, bacteria and HNF, phytoplankton biomass (Chl- $a$ concentration) and mean body size of $A$. priodonta. The abbreviations of species are: $\mathrm{C}=$ Coelastrum spp.; $\mathrm{E}=$ Euglena spp.; $\mathrm{K}=$ Keratella cochlearis; $\mathrm{P}=$ Polyarthra $\mathrm{spp}$.

The species-environment correlations of CCA axis 1 and 2 are high and the first two axis account for $70.1 \%$ of the variance in the diet composition-environment relationships. The projection of vectors representing the gradient of rotifer abundance and Chl- $a$ concentration showed that the rotifers, K. cochlearis and Polyarthra spp., and some phytoplankton preys were predominantly found in the diets where these preys are more abundant (Fig. 6).

\section{DISCUSSION AND CONCLUSION}

Regardless of species, the density of Asplanchna showed a positive correlation with the trophic status of the pond, meaning a highly eutrophicated pond had more abundant Asplanchna. Although cyclopoid copepods, their main predator (Brandl 2005), were frequently observed, a relationship between Asplanchna abundance and copepod abundance was not observed. It has been reported that the rotifer abundance in a habitat is often determined by food supply rather than predation pressure (Yoshida et al. 2003). The abundant food organisms in eutrophic environments might support high abundances of Asplanchna and it is likely that the distribution and absolute abundance of Asplanchna is controlled by so called "bottom-up" control. However, with regard to the distribution of Asplanchna species composition, they showed no species-specific preference for any biotic or abiotic factors investigated in the present study. It has been reported that Asplanchna species occur randomly among sites of similar water quality and trophic conditions, from meso- to eutrophic environments (Sládeček 1983). Thus, it may be thought that they occasionally disperse and distribute among local habitats.

The Asplanchna species showed quite different diet compositions among our ponds, and often there was no overlap in diet content even among the same species in different ponds. However, their feeding habits could be categorized according to the species since different species consumed different prey groups. A. herricki included only particulate matter in their guts, and no individual of $A$. herricki consumed identifiable phytoplankton or zooplankton prey during the present study. Thus it is likely that they are detritivores rather than herbivores or carnivores. Although diets of both $A$. priodonta and $A$. girodi included same protozoa prey such as Codonella, A. girodi showed a wide range of prey items, often also consuming zooplankton. Their different feeding habits were clearly shown by individuals collected from the same habitat, ponds 5 and 11 . Despite the fact that they were exposed to the same prey composition in the same habitat, their diets were different with a low overlap index. Salt (1989) also compared the diet composition of $A$. girodi and $A$. priodonta in the same habitat (San Joaquin-Sacramento delta of California), and suggested that $A$. girodi is more predaceous than A. priodonta. Kappes et al. (2000) and Pociecha \& Wilk-Woźniak (2008) have also suggested that $A$. priodonta is a grazer rather than a predator from the results of their analysis of its diets. Thus, it seems that Asplanchna species have strong, species-specifically different feeding habits. 
The factors determining the feeding habits of rotifers can be expected to be internal factors such as trophi structure and feeding ability (capture and ingestion abilities) and external factors such as physical and chemical environmental factors, or prey abundance limiting or promoting their feeding (Salt 1987). For the genus Asplanchna, morphotypes and trophi morphology have already been suggested as important factors deciding their species-specific feeding habits (Salt et al. 1978; Hampton \& Starkweather 1998). However, all three Asplanchna species investigated in the present study have the same campanulate morphotype. The genus Asplanchna has incudate type trophi with elongated rami (Fig. 1). Although $A$. girodi has a different shape of rami, having more sharpened rami tips, A. herricki and $A$. priodonta have very similar rami morphologies (Jersabek et al. 2003). Thus, the present results suggest that there exist other factors determining their species-specific feeding habits rather than their morphology and trophi structure.

Salt (1989) attributed the different diets of $A$. girodi and $A$. priodonta to the differences in feeding performance caused by their different sizes and resultant swimming behavior. During the present study, the differences in their body sizes were subtle and average body sizes throughout the study ponds were only different between $A$. girodi and $A$. priodonta (ANOVA with Fisher's post hoc test, $p<0.05$ ). Their body sizes were significantly different at pond 11 ( $t$-test, $p<0.005)$ but not at pond 5 $(t$-test, $p=1.244)$. Since their diet overlap index was much lower at pond $11(0.267)$ than at pond $5(0.348)$, it cannot be denied that larger body size induces more predacious feeding habits probably due to better ability to capture and ingest a wide size range of prey organisms. This explanation cannot account, however, for the different feeding habit of $A$. herricki, since A. herricki did not show significantly different body sizes from both the other species. A. herricki's diet is totally different from the others, containing only particulate materials. Compared with other Asplanchna species, the diet and feeding behavior of $A$. herricki have rarely been studied and, to our knowledge, no available information exists on its diets. Although further discussion is not possible because we did not carry out direct observation of their feeding behavior, our results do suggest that their different feeding habits may involve other factors as well as body size, such as sensory organs related to feeding (sensory receptor) or feeding abilities (ingestion or rejection) that have been suggested as factors determining rotifers' feeding behaviors (Salt 1987).

$A$. girodi often consumed rotifer prey, but positive selection was only observed for Keratella cochlearis. For other prey rotifers, even though various species were consumed, individual numbers included in the gut were low and $A$. girodi showed rather negative selection of them. In many laboratory experiments, where Asplanchna was given single or limited rotifer species in high abundance, Asplanchna might actively consume given prey species (Gilbert 1980b). However, in natural habitats, it seems that they positively select only $K$. cochearis and less actively and positively consume other rotifers. It seems that they occasionally consume the rotifer prey that they encounter when swimming.

This can also explain the highly variable diet composition of $A$. priodonta without any clear trend. The amount consumed by $A$. priodonta showed no close relationship with prey abundances in our stepwise multiple regression analysis. Although it's diet composition was partly explained by the prey abundances in a CCA analysis (particularly the relationship between rotifer consumption and rotifer abundances in the ponds), the two-dimensional graph of the CCA did not clearly partition the prey groups (phytoplankton, zooplankton and protozoa prey groups) into different clusters (Fig. 6). The gradient of HNF abundance was suggested as a related factor for the diet composition. Further discussion about their relationships is difficult in the present paper since we could not analyze the amounts of bacteria and HNF consumed by the Asplanchna species. However, the fact that variances of bacterial and HNF abundances were not related to the Asplanchna abundances in the ponds, suggests that their relationship as prey-predator might be weak.

From our results, it appears that each species of the genus Asplanchna plays a different role in the food web. It seems that $A$. herricki is a detritivore while $A$. priodonta and $A$. girodi are omnivores, but $A$. girodi is more predacious. It seems that they occasionally consume abundant prey organisms, and the amount consumed by Asplanchna was often not high enough to suppress prey densities. It can be expected that predation by Asplanchna could have an apparent impact on prey populations only when they reach high density. However, the predation impact by Asplanchna, particularly $A$. girodi works selectively on rotifer populations with high prey selectivity on Keratella cochlearis.

\section{ACKNOWLEDGMENT}

We thank Ninomiya I., Yamamoto T., Ando, T., Nishihara N., Imai H. and Kajimoto A. for their assistance during the sampling. Many thanks are due to Dr. A. Subramanian and three anonymous reviewers for their critical reading of this article and valuable comments. This study was supported by the Ministry of Education, Culture, Sports, Science and Technology, Japan (MEXT) through Global-COE Program in Ehime University.

\section{REFERENCES}

Adrian, R. \& T.M. Frost. 1993. Omnivory in cyclopoid copepods: comparisons of algae and invertebrates as food for three, differently sized species. J. Plankton Res., 15: 643-658.

Brandl, Z. 2005. Freshwater copepods and rotifers: predators and their prey. Hydrobiologia, 546: 475-489. 
Caron, D.A. 1983. Technique for enumeration of heterotrophic and phototrophic nanoplankton, using epifluorescence microscopy, and comparison with other procedures. Appl. Environ. Microbiol., 46: 491-498.

Chesson, J. 1978. Measuring preference in selective predation. Ecology, 59: 211-215.

Colin, S.P., J.H. Costello, W.M. Graham \& J. Higgins. 2005. Omnivory by the small cosmopolitan hydromedusa, Aglaura hemistoma. Limnol. Oceanogr., 50: 1264-1268.

Culver, D.A., M.M. Boucherle, D.J. Bean \& J.W. Fletcher. 1985. Biomass of freshwater crustacean zooplankton from length-weight regressions. Can. J. Fish. Aquat. Sci., 42: 1380-1390.

Dumont, H.J. \& S.S.S. Sarma. 1995. Demography and population growth of Asplanchna girodi (Rotifera) as a function of prey (Anuraeopsis fissa) density. Hydrobiologia, 306: 97-107.

Dumont, H.H., I. Van De Velde. \& S. Dumont. 1975. The dry weight estimate of biomasses in a selection of Cladocera, Copepoda and Rotifera from the plankton, periphyton and benthos of continental waters. Oecologia (Berl.), 19: 75-97.

Fernando, C.H., C. Tudorancea \& S. Mengestou. 1990. Invertebrate zooplankton predator composition and diversity in tropical lentic waters. Hydrobiologia, 198: 13-31.

Gifford, S.M., G. Rollwagen-Bollens \& S.M. Bollens. 2007. Mesozooplankton omnivory in the upper San Francisco Estuary. Mar. Ecol. Prog. Ser., 348: 33-46.

Gilbert, J.J. 1980a. Feeding in the rotifer Asplanchna: behavior, cannibalism, selectivity, prey defenses, and impact on rotifer communities. In: W.C. Kerfoot (Ed.), Evolution and Ecology of zooplankton communities. The University Press of New England, Hanover, N.H.: 158-172.

Gilbert, J.J. 1980b. Observations on the susceptibility of some protists and rotifers to predation by Asplanchna girodi. Hydrobiologia, 73: 87-91.

Haberman, J. \& R. Laugaste. 2003. On characteristics reflecting the trophic state of large and shallow Estonian lakes (L. Peipsi, L. Võrtsjärv). Hydrobiologia, 506-509: 737-744.

Hampton, S.E. \& P. Starkweather. 1998. Differences in predation among morphotypes of the rotifer Asplanchna silvestrii. Freshwat. Biol., 40: 595-605.

Jersabek, C.D., H. Segers \& P.J. Morris. 2003. An illustrated online catalog of the Rotifera in the Academy of Natural Sciences of Philadelphia (version 1.0: 2003-April-8). [WWW database] URL http://rotifer.acnatsci.org/rotifer. php.

Kappes, H., C. Mechenich \& U. Sinsch. 2000. Long-term dynamics of Asplanchna priodonta in Lake Windsborn with comments on the diet. Hydrobiologia, 432: 91-100.
Kneitel, J.M. 2007. Intermediate-consumer identity and resources alter a food web with omnivory. J. Animal. Ecol., 76: 651-659.

Maly, E.J. 1975. Interactions among the predatory rotifer Asplanchna and two prey, Paramecium and Euglena. Ecology, 56: 346-358.

Pociecha A. \& E. Wilk-Woźniak. 2008. Comments on the diet of Asplanchna priodonta (Gosse, 1850) in the Dobczycki dam reservoir on the basis of field sample observations. Oceanol. Hydrobiol. St., 37: 63-69.

Porter, K.G. \& Y.S. Feig. 1980. The use of DAPI for identifying and counting aquatic microflora. Limnol. Oceanogr., 25: $943-948$

Salt, G.W. 1987. The components of feeding behavior in rotifers. Hydrobiologia, 147: 271-281.

Salt, G.W. 1989. Comparisons of the diets and reproductive performances of two sympatric rotifers, Asplanchna girodi and Asplanchna priodonta. Freshwat. Biol., 22: 417-430.

Salt, G.W., G.F. Sabbadini \& M.L. Commins. 1978. Trophi morphology relative to food habits in six species of rotifers (Asplanchnidae). Trans. Amer. Micros. Soc., 97: 469-485.

Sarma, S.S.S., S. Nandini \& H.J. Dumont. 1998. Feeding preference and population growth of Asplanchna brightwelli (Rotifera) offered two non-evasive prey rotifers. Hydrobiologia, 361: 77-87.

Schoeneck, L.J. \& C.E. Williamson \& M.E. Stoeckel. 1990. Diel periodicity and selectivity in the feeding rate of the predatory copepod Mesocyclops edax. J. Plankton Res., 12: $29-40$.

Sládeček, V. 1983. Rotifers as indicators of water quality. Hydrobiologia, 100: 169-201.

Stemberger, R.S. 1990. Food limitation, spination, and reproduction in Brachionus calyciflorus. Limnol. Oceanogr., 35: 33-44.

Ter Braak, C.J.F. \& E. Smilauer. 1998. CANOCO reference manual and user's guide to CANOCO for Windows: software for canonical community ordination (version 4.5). Microcomputer Power, Ithaca, New York: 500 pp.

Urabe, J. 1992. Midsummer succession of rotifer plankton in a shallow eutrophic pond. J. Plankton Res., 14: 851-866.

Yoshida, T., J. Urabe \& J.J. Elser. 2003. Assessment of 'topdown' and 'bottom-up' forces as determinants of rotifer distribution among lakes in Ontario, Canada. Ecol. Res., 18: 639-650.

Zaret, T.M. \& A.S. Rand. 1971. Competition in tropical stream fishes: support for the competitive exclusion principle. Ecology, 52: 336-342. 